\title{
Effects of Organizational Justice on Job Outcomes: An Intervening Role of Affective Commitment
}

\author{
Ali Muhammad*1, Gul Makai ${ }^{2}$, Humera Mehboob ${ }^{3}$ \\ ${ }^{1}$ Institute of Management Studies, University of Peshawar, Peshawar, Pakistan. \\ ${ }^{2}$ Middle East College of Oman, Oman \\ ${ }^{3}$ Kohat University of Science $\mathcal{E}$ Technology, Kohat, KPK, Pakistan.
}

\begin{abstract}
This research examines a model depicting the association between distributive justice, procedural justice, affective commitment and work outcomes in a special context of higher education institutes. While prior research has extensively used organisational justice and its consequences for work outcomes, this study in particular explores the above linkage in universities of KPK Pakistan. In addition, affective commitment has been employed as a mediator in between the relation of work outcomes and justice types (procedural and distributive justice). Turnover intention and Employee performance are undertaken as pertinent work outcomes. Data from a sample of 150 working staff from selected reputed universities of the country's capital, i.e. Islamabad, were gathered and analysed for regression effects. The findings suggest that justice types (procedural and distributive) positively affect employee performance yet negatively influence turnover intention. Similarly, affective commitment positively mediates the relationship between organisational justice and employee performance but no mediation effect was found in case of turnover intention. Implications of the study are highlighted with a note on future research directions. The article ends with a short conclusion and limitations of the study.
\end{abstract}

\section{Introduction}

Since decades, western cultures have investigated Organizational Justice in their organizations; for they have been striving to achieve workplace equality. Not only have they made tremendous strides in this area, but they have achieved an established environment where their employees can now develop fair perceptions about their organizations (Cropanzano et al., 2002). Khalid and Ishaq (2015) posited that efficient and affective employees are essential for organization to achieve its objectives and goals. Many other scholars also advocate the significance of Organizational Justice research (Cropanzano et al., 2002; Janssen et al., 2010).

Closely related to the concept of Organizational Justice is Employee Commitment. Many researchers stress the importance of employee commitment and achievement of organizational goals and objectives (Cho and Treadway, 2011; Porter et al., 1974). Commitment further constitutes of three types: Affective, Continuous, and Normative Commitments (Gellatly et al., 2006; Meyer and Allen, 1991; Meyer et al., 2002; Powell and Meyer, 2004). Of these three, Affective Commitment has been mostly researched as it better gauges the intrinsic drive of employees towards achieving organizational goals in relation to their perception of Or-

*Corresponding author.

Email: dralimohmand@gmail.com ganizational Justice (Colquitt et al., 2001; Price et al., 1976). In Pakistan, however, this area is still under researched and requires special attention from Pakistani researchers. Not many studies come forth which measure the linkage between affective commitment and organisational justice. Studies which measure the effect of Organizational Justice on work outcomes with Affective commitment as a mediator are scarce and limited. The current research aims at filling this particular gap as explained below.

While extant research has been carried out in the past on the significance of work involving organizational justice and work outcomes, such as performance and turnover intentions (Adams and Berkowitz, 1965; Goodman, 1974; Greenberg, 1987), no good work has yet been conducted in the context of Pakistani organizations. It would be particularly worthwhile to test this theoretical link in Pakistani organizations, especially institutes of higher education whether or not it holds true and with what implications.

Furthermore, even though Justice Theory has been well explored by different researchers (Bies and Shapiro, 1987; Erdogan et al., 2006; Griffeth and Gaertner, 2001; Lin and Huang, 2009), few have specifically studied the mediating affect of Affective Commitment between Organizational Justice and Work Outcomes. 
Meyer et al. (2002) posited that of the three types of Organizational commitments, i.e. Affective Commitment, Normative Commitment, and Continuance Commitment, Organizational Justice is relatively strongly correlated to Affective Commitment amongst the three. Yet fewer numbers of studies have tested the intervening effect of Affective Commitment upon the relationship of work outcomes and Organizational Justice. This study is an attempt to explore the above mentioned linkage.

\section{Literature Review}

\subsection{Organizational Justice}

Interest in employees perception of justice, as they perceive their employers and organizations as to how fair they are, specifically in terms of distribution of its resources, began since Aristotelian times (Ross, 1925). But it was not till the mid-20th century, scholars began to research the topic thoroughly. Justice theory, which has been explored by numerous authors, such as Bies and Shapiro (1987); Colquitt et al. (2001); Erdogan et al. (2006); Lin and Huang (2009). Nadiri and Tanova (2010) described the concept as perception of just and fair behaviour on part of the employers as perceived by their employees. Such studies have identified three different types of organizational justice: Procedural justice, Distributive Justice, and Interactional Justice.

Folger and Konovsky (1989) differentiated between distributive justice and procedural justice. According to them the former is related to an employees perceived acceptance and appreciation of the compensation they get for their efforts; that is, how just is the organization in awarding goal/work related efforts. While the latter is related to the employees perception of the fairness and appropriateness of the procedures through which such compensation and awards are determined for such goal seeking behaviour. Though intricately related and somewhat similar, researchers have established that different work outcomes are affected differently by the different forms of justices (Folger and Konovsky, 1989; Konovsky et al., 1987). Some authors point out that their perception may even influence each other (Lind and Tyler, 1988; Miller, 2017; Tyler, 1988). For example an organizations employees may use the outcomes of their efforts as a tool to judge the procedures to be just or not, which in turn may increase or decrease their perception of organizational justice. Another example, as Thibaut and Walker (1975), is an organizations employees even evaluated unjust outcomes positively, because they positively perceived the process by which these were determined to be fair, since their input were taken during the decision making process. Fairness in result is the primary focus of employees when they compare them- selves with colleagues of similar educational and skill background. Distributed justice can greatly limit employees stress factor (Greenberg, 1990) thereby reducing their turnover intention (Loi et al., 2006).

Bies and Shapiro (1987) and (Colquitt et al., 2001) on the contrary explained the interactional justice is associated more to the employees perception of how their employers treat them. It is determined by the behavioural aspects of the employers, and whether or not they are polite and kind to their employees, and appreciate them. In organizations where employers respect and honour their employees integrity and selfrespect, interactional justice is perceived to be higher by employees of such organizations. It results in good management and employee relationships, and has a strong positive impact on work outcome (Al Afari and Elanain, 2014; Bies and Shapiro, 1987). According to Moorman (1991), interactional justice is to be investigated separately from procedural and distributive justice.

\subsection{Procedural Justice, Employee Perfor- mance, and Turnover Intention}

Procedural justice has instrumental and noninstrumental effects on procedural justice (Lind and Tyler, 1988). For example, when employees are involved in the process of procedural justice it not only has the instrumental effect on the outcomes of distributions, but also the non-instrumental effect by showing that the organization values its employees, and considers their input valuable. This positively influences employees perception of recognition which enhances performance thus generating positive results. According to Lind et al. (1990) this is crucial for citizenship behaviour of employees. Other studies have also shown that such procedural justice has positive effects on organizational results such as Khatri et al. (2001) and Yusof and Shamsuri (2006) showing that procedural justice enhances performance.

Consequently procedural justice is deemed negatively correlated with turnover intention (Daileyl and Kirk, 1992; Khatri et al., 2001). Exit behaviours such as leaving an organization is contributed to by low job satisfaction (Cotton and Tuttle, 1986; Dalessio et al., 1986; Steel and Ovalle, 1984). It also leads to other neglectful behaviours such as absentees (Gaudet, 1963; Muchinsky, 1977), increased error rate (Petty and Bruning, 1980), and late arrival at work (Adler and Golan, 1981; Farrell and Robb, 1980). On the other hand high job satisfaction leads to commitment to work (Aranya et al., 1986; Ferris and Aranya, 1983), and good citizenship behaviour (Bateman and Organ, 1983; Smith et al., 1983).

H1: Procedural justice is positively associated with 
employee performance while negatively associated with turnover intention.

\subsection{Procedural Justice and Affective Com- mitment}

As per prior literature, even though procedural justice is positively associated to commitment (Konovsky et al., 1987), it bears no such relationship with job satisfaction. But the opposite is true for distributive justice. Folger and Konovsky (1989) surmised that distributive justice is positively related to pay raise and reward allocation, while procedural justice determines loyalty and trust in a supervisor, as well as organizational commitment; that is, personal outcomes are better predicted with distributive justice, an evidence confirmed by Cropanzano and Folger (1989). They predicted that if employees perceive procedural justice to be fair it will lead to least amount of employee resentment, even if distributive justice is at its low. Therefore, it is predicted that fair perception of procedural justice can predict employees affective commitment better. Hence the second hypothesis is stated as follows:

H2. Procedural justice is positively associated with affective commitment.

\subsection{Distributive justice, Turnover Inten- tion, and Employee performance}

According to Cropanzano and Greenberg (1997), unfair and unjust treatment of employees lead to dissatisfaction in such employees, hence results in dissatisfactory work performance; thus employees dissatisfaction with and mistrust in distributive justice outcomes will increase grievances, which will increase turnover. Unjustified, inappropriate rewards system induces stress and dissatisfaction (Schwarzwald et al., 1992). Therefore we proposed the following hypothesis:

H3. Distributive justice is positively associated with employee performance and negatively associated with turnover intention.

\subsection{Affective Commitment, Turnover In- tention and Employee Performance}

The threefold theory of Organizational Commitment suggests that Affective commitment in comparison to Normative and Continuance commitment, bears a stronger relationship with different forms of Organizational Justice (Meyer et al., 2002; Siders et al., 2001). Positive organisational justice is likely to lead to employees affective commitment and potentially less job turnover. Affective commitment is reflected in many forms such as overall commitment to the organization, or commitment to a supervisor, or to a work team, etc (Clugston et al., 2000; Meyer and Herscovitch, 2001). The presence of organisational justice results in stronger organizational commitment as according to the reciprocity norm, employees who feel valued will reciprocate the organisation by displaying increased levels of affective commitment (Bishop and Dow Scott, 2000; Settoon et al., 1996).

The decision to leave an organization or continue to work is determined by where an employee stands on his/her commitment to that organization. According to Mathieu and Zajac (1990) and Tett and Meyer (1993) the more employees are committed to an organization the lesser will be their intended and actual turnover. Since there is a positive relationship between organizational commitment and affective commitment, the bleak relationship of low organizational commitment and intended turnover results in similar negative relationship between affective commitment and turnover intention. This means that low affective commitment determines high turnover intention and vice versa. This is also supported by literature on turnover (Becker et al., 1996; Tett and Meyer, 1993). On the contrary, the presence of affective commitment in an organization will motivate employees to stay there, thus resulting in low turnover. Hypothesis 4 is stated as follows:

H4. Affective commitment is negatively associated with turnover.

There exists strong evidence about the relation of affective commitment and employee performance. According to Becker et al. (1996) supervisor commitment is the most important aspect of affective commitment when determining the Job Performance of employees. It corresponds strongly to performance as compared to other aspects of performance such as co-worker relationship (Eisenberger et al., 2002). This also results in positive perception of the organization as the supervisor works for the organization and represents it. Therefore affective commitment can be concluded to make a positive effect on employee performance.

H5. Affective commitment is positively associated with employee job performance.

\subsection{Role of Affective Commitment as a me- diator in the relationship of Organiza- tional Justice and Work outcome}

Prior research suggests there is a positive connection between organisational justice and organisational commitment (Cohen-Charash and Spector, 2001). In comparison to distributive justice, procedural Justice showed a higher significant relationship with organi- 
zational commitment (Folger and Konovsky, 1989). In comparison to distributive justice, Procedural justice predicts organizational commitment in an improved manner (McFarlin and Sweeney, 2001). Likewise, Loi et al. (2006) found a more significant relation of procedural justice with that of affective commitment. When the procedures to take major decisions in organisations are fair, that would lead to higher levels of emotional attachment.

It can be conjectured that job satisfaction as one job outcome is considered as a correlate and consequence of affective commitment (Meyer and Herscovitch, 2001). Several studies have utilized theoretical frameworks employing the role of mediator of organizational commitment in the relation of satisfaction and organisational justice. We posit that work satisfaction therefore leads to organizational commitment, in such a manner that work satisfaction is mediated by turnover (Tett and Meyer, 1993). In the same vein, as organizational justice leads to greater affective commitment, it tends to affect intention to turnover and employees performance (Mathieu and Zajac, 1990). It is therefore articulated that affective commitment intermediates the relationship of work outcomes and organizational justice.

H6. Affective commitment mediated the relationship between organizational justice and work outcomes.

\section{Conceptual Framework}

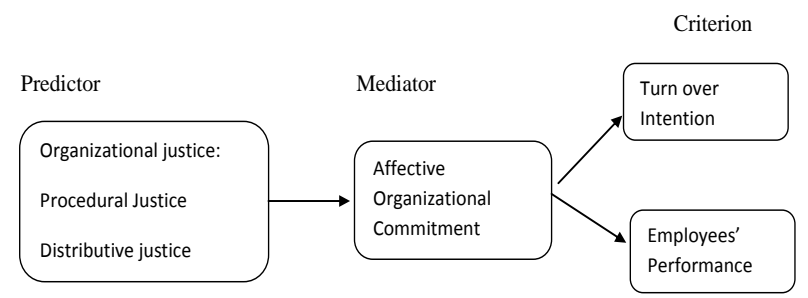

Figure 1: Mediating role of affective commitment in the relationship of organizational justice and work outcomes

\section{Methodology}

\subsection{Population and Sample}

To explore the role of organizational commitment in job outcomes, non-probability sample was taken based on teachers from several institutes of higher education. These constituted selected top-reputed universities in the state capital, i.e. Islamabad of which two were private and two were public. Namely, these universities were COMSATS, Capital University of Science \& Technology, NUST, and Quaid-e-Azam University. The first reason behind selecting this sample was that teaching community is well acquainted with turnover, job performance and is expected to exhibit profound levels of organizational commitment. So they are one of the best subjects for the course of this research. Secondly, our chosen sample has well understood the importance of research for a society therefore they have tried to render fuller attention to the survey and cooperated to the maximum. Thirdly, being part of Islamabad community, it was easier for the researcher to conduct data collection.

The approach employed for the sake of data collection in the field was Convenience sampling, which refers to the process of locating sample as per researchers comfort and convenience. It was a practical as well as economical strategy. Convenience sampling allowed the research team to take appointment from the respective University teachers at their ease and inform them of the relevance of this research. Personal relations and contacts were utilized in order to contacting them to sparing time to participate in the survey. This helped us to generate valid data repository by taking informed consent and valuable times from University teachers. Other methods of generating response rates such as Questionnaire mailing and reminders were at the same time expensive and time consuming.

A total of 240 questionnaires were distributed among University teachers, of which 224 were returned filled in with over $90 \%$ accuracy and considered valid for data analysis. Since our respondents were mostly educated, it therefore eliminated the need for translating and re-translating the questionnaire into local language. Because of prior appointments with senior faculty members, the need for a second visit did not largely arise.

In a total sample of 112 respondents the proportion of the male participants was $79(70.5 \%)$ with respect to the female respondents, i.e. 33 in number $(29.5 \%)$. As regards respondents age, highest number of participants, $33(29.5 \%)$ were in the age group 25-30. 35 respondents fall in the age group 31-35 that shows 31.5\% of the total respondents. Moreover, the age group of 3540 represent $13.4 \%$ of the respondents. About $8 \%$ lie in the age group 45 and above. Moreover, constitution of sample shows that lecturers comprised the majority of respondents $(64 \%)$ while professors were only 6 measuring to $5 \%$ in the total sample. Moreover, $30.4 \%$ of respondents totalling 34 of the total 112 respondents had 1-5 years as tenure. Similarly, people having 15 years experience were $22.3 \%$ whereas $32 \%$ had $6-10$ years as total work experience. A clear majority (57\%) were qualified with a Masters degree and almost half of the respondents were drawing an average monthly salary of 3600050000 PKR. 


\section{Results}

\subsection{Correlation Matrix and Reliability}

Table 5.1 shows that Pearson Correlation analysis was executed to present the association of independent and dependent variables. It is evident that at $p<.01$, there is a substantial positive relationship between affective commitment, justice types, and employee performance while a negative one is found among justice types, affective commitment (independent variables) and turnover intention (dependent variable).

\subsection{Regression Analysis}

Following are the results of regression analysis:

Table 5.2 shows the regression analysis for the effects of procedural and distributive justices on turnover intention and employee performance. Hypotheses were tested using SPSS version 20 . We did not take demographics as control variables in our study as they have not proven to substantially affect our selected dependent variables. The regression measures the degree of variation in dependent variable brought about by independent variable. The second hypothesis related procedural justice with affective commitment.

For the first set of hypothesis relating procedural justice and turnover intention, it is observed that $R^{2}$ value is 0.31 which means $31 \%$ change in dependent variable (turnover intention) due to one-unit change in independent variable (procedural justice). The value is -.56 which indicates that if there is $01 \%$ increase in procedural justice, turnover intention is decreased by $56 \%$. The first hypothesis suggesting procedural justice to have a negative relation with turnover intention and positive one with employee performance is supported.

The second condition of regression states that independent variable must be related to the mediator variable. In this case, correlation between procedural justice and affective commitment is .628 depicting that one percent increase in procedural justice causes $62 \%$ increase in affective commitment if other variables are controlled. The second hypothesis is thus supported.

The third hypothesis stated a positive relation of distributive justice with employee performance and negatively with turnover intention. The distributive justice $(\beta)=.204$ shows that $01 \%$ increase in distributive justice causes $20 \%$ increase in employee performance. Furthermore, for turnover intention, distributive justice $(\beta)=-.649$, shows that if there is one percent increase in procedural justice, turnover intention will be decreased by $64 \%$ when other variables are controlled. Therefore, the third hypothesis is also supported.

The fourth hypothesis implied a negative relationship of affective organizational commitment with turnover intention. Table 5.2 shows that Regression coefficient for affective commitment $(\beta)=-.801$ suggest- ing that $01 \%$ percent increase in affective commitment decreases turnover intention by $80 \%$. A negative relation is thus established and hypothesis is supported. Our fifth hypothesis stated a positive association of Affective commitment with Employee performance. The data show that regression coefficient for affective commitment $(\beta)=.181$ which implies that a $1 \%$ percent increase in affective commitment increases employee performance by $18 \%$ provided other variables are controlled. Therefore the fifth hypothesis is also validated.

\subsubsection{Regression Analysis between Procedural Justice And Employee Performance}

Regression analysis was performed to examine the independent variables (procedural and distributive justice) on dependent variables (employee performance and turnover intention) while affective commitment was used as a mediator. Model of regression is presented as under:

$$
T I=\alpha+\beta 2 P J+\varepsilon
$$

Whereas EP (employee performance)is the criterion variable

$\beta 1 \mathrm{PJ}$ (Procedural justice) is the predictor variable.

Table 5.3 shows that $\mathrm{R}=.238$ and also that there is $23 \%$ relationship between (predictor) and (criterion). $\mathrm{R} 2$ is the coefficient of determination, which is .056. It means that procedural justice (predictor) causes a total variation of $5.6 \%$ in criterion variable of employee performance.

From Table $5.4 \mathrm{~F}$ value is 6.338 which is significant $(\mathrm{P} \leq 0.05)$. The significance level means that the regression model is statistically significant, and fit.

Table 5.5 shows that standardized coefficient for procedural justice $(\beta 1)$ is .238 , which means that if predictor is increased by $1 \%$, employee performance will be increased by $23 \%$, if rest of things are kept constant. The value of $\mathrm{T}=2.517$ stands significant at .013 . This indicates that the alternate hypothesis stating that procedural justice affect employee performance is substantiated.

\subsubsection{Regression Analysis between Procedural Justice And Turnover Intention}

The regression model used for the relation of procedural justice and turnover intention is stated as follows:

$$
T I=\alpha+\beta 2 P J+\varepsilon
$$

Where TI is the dependent variable i.e. Turnover intention, and

$\beta 2 \mathrm{PJ}$ is Procedural justice, our main independent variable.

The $\mathrm{F}$ value 49.68 is smaller than $\mathrm{P} \leq 0.05$. This proves that the model stands valid, fit and significant. 
Table 5.1: Correlation Matrix and Reliability

\begin{tabular}{lccccc}
\hline & $\begin{array}{c}\text { Procedural } \\
\text { Justice }\end{array}$ & $\begin{array}{c}\text { Distributive } \\
\text { Justice }\end{array}$ & $\begin{array}{c}\text { Affective } \\
\text { Com- } \\
\text { mitment }\end{array}$ & $\begin{array}{c}\text { Employee } \\
\text { Perfor- } \\
\text { mance }\end{array}$ & $\begin{array}{c}\text { Turnover } \\
\text { Inten- } \\
\text { tion }\end{array}$ \\
\hline Procedural Justice & $(.838)$ & & & & \\
Distributive Justice & $.713^{* *}$ & $(.924)$ & & & \\
Affective Commitment & $628^{* *}$ & $.707^{* *}$ & $(.854)$ & & \\
Employee Performance & $238^{*}$ & $.204^{*}$ & .181 & $(.684)$ & \\
Turnover Intention & $-.560^{* *}$ & $-.649^{* *}$ & $-.801^{* *}$ & -.110 & $(.950)$ \\
\hline
\end{tabular}

** Significance level: 0.01 level (2-tailed).

* Significance level:0.05 level (2-tailed).

Table 5.2: Regression Analysis

\begin{tabular}{lcccccccc}
\hline Predictors & \multicolumn{1}{c}{ Outcomes } \\
\hline & \multicolumn{9}{c}{ Turnover Intention } & \multicolumn{4}{c}{ Employee performance } \\
& $\beta$ & $\mathbf{R}^{2}$ & $\Delta R^{2}$ & $\mathbf{F}$ & $\beta$ & $\mathbf{R}^{2}$ & $\Delta R^{2}$ & $\mathbf{F}$ \\
\hline Procedural Justice & $-.560^{* * *}$ & .313 & .307 & $49.56^{*}$ & $.238^{a}$ & .056 & .048 & $6.33^{* *}$ \\
Distributive justice & $-.649^{a}$ & .422 & .417 & $80.23^{* * *}$ & $.204^{a}$ & .042 & .033 & $4.66^{*}$ \\
Affective Commitment & $-.801^{a}$ & .642 & .639 & $197^{* * *}$ & $.181^{a}$ & .033 & .024 & $3.66^{*}$ \\
\hline
\end{tabular}

$$
\begin{aligned}
& { }^{*} p<.05 \\
& { }^{* *} p<.01 \\
& { }^{* *} p<.001
\end{aligned}
$$

Table 5.3: Model Summary

\begin{tabular}{ccccc}
\hline Model & R & R Square & Adjusted R Square & Std. Error \\
\hline 1 & $.238^{a}$ & .056 & .048 & .36597 \\
\hline a. Predictors: meanPj & & & &
\end{tabular}

Table 5.4: ANOVA

\begin{tabular}{cccccc}
\hline Model & Sum of Squares & df & Mean Square & F & Sig. \\
\hline Regression & .849 & 1 & .849 & 6.338 & $.013^{a}$ \\
Residual & 14.197 & 106 & .134 & & \\
Total & 15.046 & 107 & & & \\
\hline
\end{tabular}

a. Independent variable: (Constant), meanpj

b. Dependent Variable: meanep

The regression coefficient for procedural justice $(\beta 2)=-.560$ indicating that if there is $01 \%$ increase in procedural justice, turnover intention is decreased by $56 \%$ if other variables are controlled. T value -7.09 is significant at .000. It means that the alternate hypothesis stating a negative relation between procedural justice and turnover intention should be accepted.

\subsubsection{Regression Analysis between Procedural Justice And Affective Commitment}

The regression model for the relationship between procedural justice and affective commitment is stated as follows:

$$
A C=\alpha+\beta 3 P J+\varepsilon
$$


Table 5.5: Coefficients

\begin{tabular}{cccccc}
\hline Model & \multicolumn{2}{c}{ Unstandardized Coefficients } & Standardized Coefficients & t & Sig. \\
& B & Std. Error & Beta & & \\
\hline (Constant) & 3.311 & .187 & & 17.668 & .000 \\
meanpj & .140 & .056 & .238 & 2.517 & .013 \\
\hline
\end{tabular}

Dependent Variable: meanep

Table 5.6: ANOVA

\begin{tabular}{cccccc}
\hline Model & Sum of Squares & df & Mean Square & F & Sig. \\
\hline Regression & 44.988 & 1 & 44.988 & 49.689 & $.000^{a}$ \\
Residual & 98.689 & 109 & .905 & & \\
Total & 143.678 & 110 & & & \\
\hline
\end{tabular}

a. Independent: (Constant), meanpj

$b$. Dependent Variable: meanti

Table 5.7: Coefficients

\begin{tabular}{cccccccc}
\hline & Model & \multicolumn{2}{c}{$\begin{array}{c}\text { Unstandardized Coefficients } \\
\text { B }\end{array}$} & Std. Error & $\begin{array}{c}\text { Standardized Coefficients } \\
\text { Beta }\end{array}$ & t & Sig. \\
& & & B & & & \\
\hline 1 & (Constant) & 5.998 & .485 & & 12.358 & .000 \\
& meanpj & -1.011 & .143 & -.560 & -7.049 & .000 \\
\hline
\end{tabular}

Dependent Variable: meanep

Table 5.8: Coefficients

\begin{tabular}{ccccccc}
\hline \multirow{2}{*}{ Model } & \multicolumn{2}{c}{$\begin{array}{c}\text { Unstandardized Coefficients } \\
\text { B }\end{array}$} & $\begin{array}{c}\text { Standardized Coefficients } \\
\text { Std. Error }\end{array}$ & T & Sig. \\
\hline 1 & (Constant) & .998 & .341 & & 2.928 & .004 \\
& meanpj & .849 & .101 & .628 & 8.423 & .000 \\
\hline
\end{tabular}

a. Dependent Variable: meanac

Where AC is Affective commitment (dependent variable), and

$\beta 3 \mathrm{PJ}=$ Procedural justice (independent variable)

Table 5.8 shows that the regression coefficient for procedural justice $(\beta 3)$ is .628 depicting that one percent increase in procedural justice causes $62 \%$ increase in affective commitment if other variables are controlled. $T$ value 8.423 is significant at .000 . Again the alternate hypothesis stating a positively effect of procedural justice over affective commitment should be accepted.

\subsubsection{Regression Analysis between Distribu- tive Justice And Employee Performance}

Our regression equation for the relation of distributive justice and employee performance is stated as follows:

$$
E P=\alpha+\beta 4 D J+\varepsilon
$$

Where EP is Employee performance (dependent variable), and

$\beta 4 \mathrm{DJ}=$ Distributive justice is the independent variable

The Regression coefficient $\mathrm{R}=.204$ or $20 \%$ shows that $20 \%$ relationship exists between dependent and independent variables. The value of $\mathrm{R}^{2}=.042$ depicting that distributive justice causes $4.2 \%$ variation in employee performance.

$\mathrm{F}$ is 4.664 and it is less than $\mathrm{P} \leq 0.05$. This proves a regression model that is fit, valid and statistically significant.

Coefficient of Regression for distributive justice 
Table 5.9: Model Summary

\begin{tabular}{lcccc}
\hline Model & $\mathbf{R}$ & R Square & Adjusted R Square & Std. Error of the Estimate \\
\hline 1 & $.204^{a}$ & .042 & .033 & .37571 \\
\hline a. Predictors: (Constant), meandj & &
\end{tabular}

Table 5.10: ANNOVA

\begin{tabular}{ccccccc}
\hline & Model & Sum of Squares & df & Mean Square & F & Sig. \\
\hline 1 & Regression & .658 & 1 & .658 & 4.664 & $.033^{a}$ \\
& Residual & 15.104 & 107 & .141 & & \\
& Total & 15.763 & 108 & & & \\
\hline
\end{tabular}

a. Independent: (Constant), meandj

b. Dependent Variable: meanep

Table 5.11: Coefficients

\begin{tabular}{ccccccc}
\hline & Model & \multicolumn{2}{c}{ UnstandardizedCoefficients } & Standardized Coefficients & t & Sig. \\
& & B & Std. Error & & & \\
\hline 1 & (Constant) & 3.523 & .125 & & 28.104 & .000 \\
& meandj & .077 & .036 & .204 & 2.160 & .033 \\
\hline
\end{tabular}

a. Dependent Variable: meanep

$(\beta 4)=.204$ shows that $01 \%$ increase in distributive justice causes $20 \%$ increase in employee performance if other variables are controlled. T value 2.160 is significant at .033. Thus alternate hypothesis stating that distributive justice affects the employee performance should be accepted.

\subsubsection{Regression Analysis between Distribu- tive Justice And Turnover Intention}

The specific regression equeation for the relation of distributive justice and turnover intention is:

$$
T I=\alpha+\beta 5 D J+\varepsilon
$$

Where TI is the dependent variable, and

$\beta 5 \mathrm{DJ}=$ Distributive justice is the independent variable

The coefficient of regression for distributive justice $(\beta 5)=-.649$, shows that if there is one percent increase in procedural justice, turnover intention will be decreased by $64 \%$ when other variables are controlled. $T$ value is -8.95 and is significant at .000 . This proves that the alternate hypothesis will be accepted. The alternate hypothesis was such that distributive justice negatively affects the turnover intention.

\subsubsection{Regression Analysis between Affective Commitment and Turnover Intention}

The regression model for the relation between Affective commitment and Turnover intention is stated as follows:

$$
T I=\alpha+\beta 6 A C+\varepsilon
$$

Where TI is the dependent variable, and

$\beta 6 \mathrm{AC}=$ Affective commitment is the independent variable.

Coefficient of Regression for affective commitment is $(\beta 6)=-.801$ which shows that turnover intention decreases by $80 \%$ when affective commitment rises by $01 \%$ provided other things are controlled for. The T value is -14.04 is thus significant at .000 . The alternate hypothesis stands accepted. It was stated as affective commitment negatively affects turnover intention.

\subsubsection{Regression Analysis between Affective Commitment and Employee Performance}

As per the usual regression model, the equation for the relationship of Affective commitment and Employee performance is stated as follows:

$$
E P=\alpha+\beta 7 A C+\varepsilon
$$


Table 5.12: Coefficients

\begin{tabular}{ccccccc}
\hline & Model & \multicolumn{2}{c}{ Unstandardized Coefficients } & Standardized Coefficients & t & Sig. \\
& & B & Std. Error & & & \\
\hline 1 & (Constant) & 5.104 & .286 & -.649 & 17.831 & .000 \\
& meandj & -.730 & .081 & -8.959 & .000 \\
\hline
\end{tabular}

a. Dependent Variable: meanti

Table 5.13: Coefficients

\begin{tabular}{ccccccc}
\hline & Model & \multicolumn{2}{c}{ Unstandardized Coefficients } & Standardized Coefficients & t & Sig. \\
& & B & Std. Error & & Beta & \\
\hline 1 & (Constant) & 6.768 & .300 & & 22.535 & .000 \\
& meanac & -1.078 & .077 & -.801 & -14.048 & .000 \\
\hline
\end{tabular}

a. Dependent Variable: meanti

Table 5.14: Coefficients

\begin{tabular}{ccccccc}
\hline \multirow{2}{*}{ Model } & \multicolumn{2}{c}{ Unstandardized Coefficients } & Standardized Coefficients & t & Sig. \\
& & B & Std. Error & Beta & & \\
\hline 1 & (Constant) & 3.473 & .166 & & 20.923 & .000 \\
& meanac & .081 & .042 & .181 & 1.906 & .059 \\
\hline
\end{tabular}

Dependent Variable: meanep

Where EP is the dependent variable, and

$\beta 7 \mathrm{AC}=$ Affective commitment is the independent variable

Coefficient of regression for affective commitment $(\beta 7)=.181$ stating that employee performance is increased by $18 \%$ when affective commitment is increased by $1 \%$ with other variables being controlled. The $T$ value is 1.906 and is significant at .059, thus alternate hypothesis "affective commitment (predictor) positively affects the employee performance (criterion)" would be accepted.

\subsubsection{Results After Introducing Mediation Ef- fects}

The above table illustrates two cases:

- When there was no mediator between independent (procedural and distributive justice) and dependent variable (employee performance).

- When there was a mediator between dependent and independent variables.

In the first case, the mean values of two justice types are .118 and .019 respectively when their impact was found on employee performance. However when mediator was added to the equation, the values of procedural justice and distributive justice were reduced to .113 and .012 respectively. This means with the involvement of mediator, the bond became rather insignificant.

This table also shows two cases:

- When there was no mediator between independent (procedural and distributive justice) and dependent variable (turnover intention).

- When there was a mediator between the predictor and criterion variable

The first case finds that the mean values of justice types are -.323 and -.597 respectively, when their impact altogether was found on turnover intention. But after the addition of mediator in the second stage, the mean values of two types of justices became -.013 and -.196 with no mediation effect. Thus in the two cases, mediation had an effect in the employee performance case but not in turnover intention case.

\section{Discussion and Conclusion}

The current study aimed to explore the association of selected types of justices (procedural and distributive) and how it impacted employees' turnover 
intention and their job performance. Furthermore, it also wanted to find out role of affective commitment as a mediating variable between them. In light of these aims, this study throws light on the negative consequences of organizational injustice on employee turnover and job performance. In consistence with (Cho and Treadway, 2011), this study brought forward confirmations for the association of procedural justice and distributive justice with employees' work outcome specifically their turnover intention and affected performance. Moreover, this study illuminated that employee commitment is significantly affected by procedural and distributive justice. Lastly, in pursuit of filling the research gap, it identified the mediating role of affective commitment between organizational justice and employee work outcomes. This study effectively completed the research objectives and in turn fulfilled the research gap, thus contributing to the extant litera- ture, as well as holding practical implications for policy development and implementations for Pakistani organizations.

The data were gained from selective reputed universities situated in Islamabad. After a rigorous analysis of the relation among the three different constructs, i.e. justice types, affective commitment and job outcomes, it can be asserted that our postulated hypotheses are mostly positive and significant. Based on the results $(\beta 1)=.238$ and $(\beta 2)=-.560$, the first hypothesis proves to be supportive stating that procedural justice is positively related to employee performance and negatively towards turnover intention. Similarly, the second hypothesis that procedural justice is positively related to affective commitment is also supported. Further, hypothesis 3 is supported such that distributive justice is positively related to employee performance and negatively associated with turnover intention. Hy-

Table 5.15: Coefficients

\begin{tabular}{lcc}
\hline Model & B & Sig \\
\hline Constant & 3.320 & .000 \\
Meanpj & .118 & .149 \\
Meandj & .019 & .714 \\
After the addition of mediator & & \\
Constant & 3.472 & .000 \\
Mean ac & .079 & .060 \\
Constant & 3.303 & .000 \\
Mean Ac & .015 & .815 \\
Meanpj & .015 & .182 \\
Meandj & .012 & .840 \\
\hline
\end{tabular}

Dependent variable: meanep

Table 5.16: Coefficients

\begin{tabular}{lcc}
\hline Model & B & Sig \\
\hline (Constant) & 5.717 & .000 \\
Meanpj & -.323 & .081 \\
Meandj & -.597 & .000 \\
After the addition of mediator & & \\
Constant & 6.767 & .000 \\
Mean ac & -1.081 & .000 \\
Constant & 6.813 & .000 \\
Mean ac & -.909 & .000 \\
Mean pj & -.013 & .929 \\
Mean dj & -.196 & .054 \\
\hline
\end{tabular}

Dependent variable: meanti 
pothesis 4 and 5 are also supported by the findings $(\beta 6)=-.801$ (turnover intention) and $(\beta 7)=.181$. In the end, hypothesis 6 substantiates the mediating role of Affective commitment for employee performance but not supported for turnover intention.

\subsection{Practical Implication}

Although this study offers vast implications, the most important of them to note is that the prevalence of unfair procedures and injustice in organizations have strong negative implications for employees' performance. Furthermore, as was proved by hypothesis number 6 , the mediating role of affective commitment demands that the organizations in question should ultimately strive for the prevalence of justice to warrant its employees' commitment, which will in turn work towards enhancing their performance. They should responsibly endeavour to keep minimizing injustice in organizations and to ultimately eliminate them. This study explains the variations in employee behaviour and performance that occur due to justice and affective commitment.

\subsection{Future Research Directions}

This paper holds potential implications for future research endeavours into the topic at hand. It can be further researched with various other related topics such as burnout, organizational stress, employee motivation, and deviance, etc. It also contributes to the extant literature if new concepts are taken into account whose determinants are not previously researched. Studying this model in different contexts and sociopolitical background may also lend to new streams commitment contributions leading to further consequences of organizational justice. Models with different moderators and mediators should also be taken into consideration. .

\subsection{Limitation of Study}

As the nature of this study is grounded its foundations on cross sectional data. Following this up with a longitudinal design will enrich the findings and explore further avenues of contributions to the antecedents and consequents. Furthermore, the selfreporting method of data collection might be riddled with common method error. Lastly, the mediation difference between the means of procedural justice and distributive, though showing significant results, is still small.

Nevertheless, this particular study has attempted to fill in the gap in the literature on justice and commitment. It has presented interesting findings that attract and invite other researchers for undertaking further research more rigorously. Though, it is not possible to en- tirely drive out the presence of injustice in workplace, but this study might help relevant personnel to control the outcomes of these constructs in an improved manner.

\section{References}

Adams, J. S. and Berkowitz, L. (1965). Advances in experimental social psychology. Advances in experimental social psychology, 2.

Adler, S. and Golan, J. (1981). Lateness as a withdrawal behavior. Journal of Applied Psychology, 66(5):544.

Al Afari, T. S. and Elanain, H. M. A. (2014). Procedural and distributive justice as mediators of the relationship between interactional justice and work outcomes: An empirical study of the uae public health care sector. Journal of Applied Business Research, 30(4):1091.

Aranya, N., Kushnir, T., and Valency, A. (1986). Organizational commitment in a male dominated profession. $\mathrm{Hu}$ man Relations, 39(5):433-448.

Bateman, T. S. and Organ, D. W. (1983). Job satisfaction and the good soldier: The relationship between affect and employee citizenship. Academy of management Journal, 26(4):587-595.

Becker, T. E., Billings, R. S., Eveleth, D. M., and Gilbert, N. L. (1996). Foci and bases of employee commitment: Implications for job performance. Academy of management journal, 39(2):464-482.

Bies, R. J. and Shapiro, D. L. (1987). Interactional fairness judgments: The influence of causal accounts. Social Justice Research, 1(2):199-218.

Bishop, J. W. and Dow Scott, K. (2000). An examination of organizational and team commitment in a self-directed team environment. Journal of Applied Psychology, 85(3):439.

Cho, J. and Treadway, D. C. (2011). Organizational identification and perceived organizational support as mediators of the procedural justice-citizenship behaviour relationship: A cross-cultural constructive replication. European Journal of Work and Organizational Psychology, 20(5):631-653.

Clugston, M., Howell, J. P., and Dorfman, P. W. (2000). Does cultural socialization predict multiple bases and foci of commitment? Journal of management, 26(1):5-30.

Cohen-Charash, Y. and Spector, P. E. (2001). The role of justice in organizations: A meta-analysis. Organizational behavior and human decision processes, 86(2):278-321.

Colquitt, J. A., Conlon, D. E., Wesson, M. J., Porter, C. O., and $\mathrm{Ng}$, K. Y. (2001). Justice at the millennium: a meta-analytic review of 25 years of organizational justice research. Journal of applied psychology, 86(3):425.

Cotton, J. L. and Tuttle, J. M. (1986). Employee turnover: A meta-analysis and review with implications for research. Academy of management Review, 11(1):55-70. 
Cropanzano, R. and Folger, R. (1989). Referent cognitions and task decision autonomy: Beyond equity theory. Journal of applied psychology, 74(2):293.

Cropanzano, R. and Greenberg, J. (1997). Progress in organizational justice: Tunneling through the maze. International review of industrial and organizational psychology, 12:317-372.

Cropanzano, R., Prehar, C. A., and Chen, P. Y. (2002). Using social exchange theory to distinguish procedural from interactional justice. Group $\mathcal{E}$ Organization Management, 27(3):324-351.

Daileyl, R. C. and Kirk, D. J. (1992). Distributive and procedural justice as antecedents of job dissatisfaction and intent to turnover. Human Relations, 45(3):305-317.

Dalessio, A., Silverman, W. H., and Schuck, J. R. (1986). Paths to turnover: A re-analysis and review of existing data on the mobley, horner, and hollingsworth turnover model. Human Relations, 39(3):245-263.

Eisenberger, R., Stinglhamber, F., Vandenberghe, C., Sucharski, I. L., and Rhoades, L. (2002). Perceived supervisor support: Contributions to perceived organizational support and employee retention. Journal of applied psychology, 87(3):565.

Erdogan, B., Liden, R. C., and Kraimer, M. L. (2006). Justice and leader-member exchange: The moderating role of organizational culture. Academy of Management journal, 49(2):395-406.

Farrell, D. and Robb, D. (1980). Lateness to work: A study of withdrawal from work. In annual meeting of the Academy of Management, Detroit.

Ferris, K. R. and Aranya, N. (1983). A comparison of two organizational commitment scales. Personnel psychology, 36(1):87-98.

Folger, R. and Konovsky, M. A. (1989). Effects of procedural and distributive justice on reactions to pay raise decisions. Academy of Management journal, 32(1):115-130.

Gaudet, F. (1963). Solving the problems of employee absence (ama research study 57). new york: American management association. Inc. Google Scholar.

Gellatly, I. R., Meyer, J. P., and Luchak, A. A. (2006). Combined effects of the three commitment components on focal and discretionary behaviors: A test of meyer and herscovitchs propositions. Journal of vocational behavior, 69(2):331345.

Goodman, L. A. (1974). The analysis of systems of qualitative variables when some of the variables are unobservable. part ia modified latent structure approach. American Journal of Sociology, 79(5):1179-1259.

Greenberg, J. (1987). A taxonomy of organizational justice theories. Academy of Management review, 12(1):9-22.

Greenberg, J. (1990). Organizational justice: Yesterday, today, and tomorrow. Journal of management, 16(2):399-432.
Griffeth, R. W. and Gaertner, S. (2001). A role for equity theory in the turnover process: An empirical test. Journal of Applied Social Psychology, 31(5):1017-1037.

Janssen, O., Lam, C. K., and Huang, X. (2010). Emotional exhaustion and job performance: The moderating roles of distributive justice and positive affect. Journal of Organizational Behavior, 31(6):787-809.

Khalid, S. and Ishaq, S. (2015). Job related outcomes in relation to perceived organizational politics. Pakistan Economic and Social Review, 53(1):133.

Khatri, N., Fern, C. T., and Budhwar, P. (2001). Explaining employee turnover in an asian context. Human Resource Management Journal, 11(1):54-74.

Konovsky, M. A., Folger, R., and Cropanzano, R. (1987). Relative effects of procedural and distributive justice on employee attitudes. Representative research in social psychology, 17(1):15-24.

Lin, T.-C. and Huang, C.-C. (2009). Understanding social loafing in knowledge contribution from the perspectives of justice and trust. Expert Systems with Applications, 36(3):6156-6163.

Lind, E. A., Kanfer, R., and Earley, P. C. (1990). Voice, control, and procedural justice: Instrumental and noninstrumental concerns in fairness judgments. Journal of Personality and Social psychology, 59(5):952.

Lind, E. A. and Tyler, T. R. (1988). Procedural justice in organizations. In The social psychology of procedural justice, pages 173-202. Springer.

Loi, R., Hang-Yue, N., and Foley, S. (2006). Linking employees' justice perceptions to organizational commitment and intention to leave: The mediating role of perceived organizational support. Journal of Occupational and Organizational Psychology, 79(1):101-120.

Mathieu, J. E. and Zajac, D. M. (1990). A review and meta-analysis of the antecedents, correlates, and consequences of organizational commitment. Psychological bulletin, 108(2):171.

McFarlin, D. B. and Sweeney, P. D. (2001). Cross-cultural applications of organizational justice. Justice in the workplace: From theory to practice, 2:67-95.

Meyer, J. P. and Allen, N. J. (1991). A three-component conceptualization of organizational commitment. Human resource management review, 1(1):61-89.

Meyer, J. P. and Herscovitch, L. (2001). Commitment in the workplace: Toward a general model. Human resource management review, 11(3):299-326.

Meyer, J. P., Stanley, D. J., Herscovitch, L., and Topolnytsky, L. (2002). Affective, continuance, and normative commitment to the organization: A meta-analysis of antecedents, correlates, and consequences. Journal of vocational behavior, 61(1):20-52. 
Miller, D. (2017). Distributive justice: What the people think. In Distributive Justice, pages 135-173. Routledge.

Moorman, R. H. (1991). Relationship between organizational justice and organizational citizenship behaviors: Do fairness perceptions influence employee citizenship? Journal of applied psychology, 76(6):845.

Muchinsky, P. M. (1977). Employee absenteeism: A review of the literature. Journal of Vocational Behavior, 10(3):316-340.

Nadiri, H. and Tanova, C. (2010). An investigation of the role of justice in turnover intentions, job satisfaction, and organizational citizenship behavior in hospitality industry. International journal of hospitality management, 29(1):33-41.

Petty, M. and Bruning, N. S. (1980). Relationship between employees' attitudes and error rates in public welfare programs. Academy of Management Journal, 23(3):556-561.

Porter, L. W., Steers, R. M., Mowday, R. T., and Boulian, P. V. (1974). Organizational commitment, job satisfaction, and turnover among psychiatric technicians. Journal of applied psychology, 59(5):603.

Powell, D. M. and Meyer, J. P. (2004). Side-bet theory and the three-component model of organizational commitment. Journal of vocational behavior, 65(1):157-177.

Price, J., Dewire, J., Nowack, J., Schenkel, K., and Ronan, W. (1976). Three studies of grievances. Personnel Journal, 55(1):33-37.

Ross, W. (1925). The oxford translation of aristotle, vol. ix: The nichomachean ethics.

Schwarzwald, J., Koslowsky, M., and Shalit, B. (1992). A field study of employees' attitudes and behaviors after promotion decisions. Journal of applied psychology, 77(4):511.
Settoon, R. P., Bennett, N., and Liden, R. C. (1996). Social exchange in organizations: Perceived organizational support, leader-member exchange, and employee reciprocity. Journal of applied psychology, 81(3):219.

Siders, M. A., George, G., and Dharwadkar, R. (2001). The relationship of internal and external commitment foci to objective job performance measures. Academy of Management Journal, 44(3):570-579.

Smith, C., Organ, D. W., and Near, J. P. (1983). Organizational citizenship behavior: Its nature and antecedents. Journal of applied psychology, 68(4):653.

Steel, R. P. and Ovalle, N. K. (1984). A review and metaanalysis of research on the relationship between behavioral intentions and employee turnover. Journal of applied psychology, 69(4):673.

Tett, R. P. and Meyer, J. P. (1993). Job satisfaction, organizational commitment, turnover intention, and turnover: path analyses based on meta-analytic findings. Personnel psychology, 46(2):259-293.

Thibaut, J. W. and Walker, L. (1975). Procedural justice: A psychological analysis. L. Erlbaum Associates.

Tyler, T. R. (1988). What is procedural justice?: Criteria used by citizens to assess the fairness of legal procedures. Law and Society Review, pages 103-135.

Yusof, A. and Shamsuri, N. (2006). Organizational justice as a determinant of job satisfaction and organizational commitment. Malaysian Management Review, 41(1):47-62. 